\title{
Identification of long-range chromatin interactions between HTLV-1 and the host genome
}

\author{
Hiroko Yaguchi ${ }^{1 *+}$, Anat Melamed ${ }^{1 \dagger}$, Aileen Rowan ${ }^{1}$, Lucy Cook', Yorifumi Satou ${ }^{1,2}$, Charles R M Bangham ${ }^{1}$ \\ From 17th International Conference on Human Retroviruses: HTLV and Related Viruses \\ Trois Ilets, Martinique. 18-21 June 2015
}

Human T-lymphotropic virus type I (HTLV-1) integration is known to be weakly biased towards genomically active regions but can occur throughout the genome. We have shown that there are of the order of $10^{\wedge} 4$ HTLV-1-infected $\mathrm{T}$-cell clones in each individual, each clone defined by a unique genomic integration site of the single-copy HTLV1 provirus. HTLV-1 dysregulates many host genes by expressing a transcriptional transactivator, Tax, but it remains unknown whether HTLV-1 also alters host gene expression by insertional mutagenesis. In recent work (Satou et al, submitted) we have shown that HTLV-1 encodes a functional binding site for CCCTC binding factor (CTCF), a known mediator of chromatin looping. We hypothesize that the HTLV-1 provirus forms CTCFmediated chromatin loops with the flanking host genome and dysregulates the expression of host genes. To test this hypothesis, we performed a circular chromatin conformation capture assay followed by high-throughput sequencing (4C-seq) which enables high resolution screening of physical long range interactions between chromosomes. Using the proviral CTCF site as bait, we have detected long-range interactions between the proviral and the host genome which suggest the formation of novel chromatin looping in clones of HTLV-1-infected T cells from both cases of ATL and from non-malignant cases of HTLV-1 infection. Chromosome conformation capture using specific primers (3C) confirmed clone-specific interactions. We are now testing whether these long-range interactions are associated with clone-specific alterations in the expression of host genes.

\footnotetext{
Authors' details

${ }^{1}$ Imperial College London, London, W2 1PG, UK. ${ }^{2}$ Kumamoto University, Kumamoto, 860-0811, Japan.
}

\footnotetext{
* Correspondence: h.yaguchi@imperial.ac.uk

+ Contributed equally

${ }^{1}$ Imperial College London, London, W2 1PG, UK

Full list of author information is available at the end of the article
}

Published: 28 August 2015

doi:10.1186/1742-4690-12-S1-010

Cite this article as: Yaguchi et al:: Identification of long-range chromatin interactions between HTLV-1 and the host genome. Retrovirology 2015 12(Suppl 1):010.
Submit your next manuscript to BioMed Central and take full advantage of:

- Convenient online submission

- Thorough peer review

- No space constraints or color figure charges

- Immediate publication on acceptance

- Inclusion in PubMed, CAS, Scopus and Google Scholar

- Research which is freely available for redistribution

Submit your manuscript at www.biomedcentral.com/submit
C Biomed Central 